\title{
Comparison of Medcem MTA, Medcem Pure Portland Cement and NeoMTA to Pediatric Restorative Materials to Shear Bond Strength
}

\author{
Medcem MTA, Medcem Saf Portland Siman ve NeolMTA'nın Pediatrik Restoratif \\ Materyallere Makaslama Bağ Dayanımlarının Karşılaştırılması
}

\author{
Sacide DUMAN ${ }^{* 1}(1)$ \\ sacidetuncduman@gmail.com
}

\author{
Ahmet ÇALIŞKAN ${ }^{2}$ (D) \\ dt.ahmetcaliskan@gmail.com
}

Seçil ÇALIŞKAN ${ }^{3}$ iD

sclctn@hotmail.com

\begin{abstract}
Aim: The aim of this study is to compare the shear bond strength of Medcem Pure Portland Cement, Medcem MTA and NeoMTA, which are used in vital pulp treatments, to different pediatric restorative materials.

Materials and Method: Standard acrylic blocks $(4 * 2 \mathrm{~mm})$ were prepared for the shear bond strength test. The calcium silicate-based biomaterials (Medcem MTA, Medcem Pure Portland Cement, NeoMTA) were prepared in accordance with the manufacturer's instructions. They were inserted into the holes in the acrylic blocks and left the recommended time to harden. The restorative materials were evaluated in 4 groups (compomer, resin modified glass ionomer cement, high viscosity glass ionomer cement, Cention $\mathrm{N}$ ). the restorative materials were applied on the biomaterials with the help of cylindrical molds (diameter of $2 * 2 \mathrm{~mm}$ ). The data obtained were analyzed using one-way tests of ANOVA and Turkey. Results: While the restorative material group showing the highest shear bond strength with Medcem Pure Portland cement is the high viscosity glass ionomer cement group, it was followed by the compomer, Cention $\mathrm{N}$ and resin modified glass ionomer cement groups, respectively. The shear bond strength between Medcem MTA and compomer group was the highest, followed respectively by Cention $\mathrm{N}$, resin modified glass ionomer cement and high viscosity glass ionomer cement groups. On the other hand, in NeoMTA the highest shear bond strength was determined by the Cention N group, and the lowest by the high viscosity glass ionomer cement group.

Conclusion: The shear bond strength between the biomaterials and pediatric restorative materials used in this study is promising and can be considered as an alternative in vital pulp treatments.
\end{abstract}

Keywords: Shear bond strength, Calcium silicate cement, Vital pulp treatment

$\begin{array}{lll}\text { Received: } 18.11 .2021 & \text { Accepted: 22.12.2021 Published: } 29.12 .2021\end{array}$

\section{öz}

Amaç: Bu çalışmanın amacı, vital pulpa tedavilerinde kullanılan Medcem Saf Portland siman, Medcem MTA ve NeoMTA'nın farklı pediatrik restoratif materyallere makaslama bağ dayanımını karşılaștırmaktır.

Gereç ve Yöntemler: Makaslama bağ dayanım testi için standart akrilik bloklar $(4 * 2 \mathrm{~mm})$ hazırlandı. Üretici firmaların talimatları doğrultusunda hazırlanan kalsiyum silikat içerikli biyomateryaller (Medcem MTA, Medcem Saf Portland siman, NeoMTA) akrilik bloklardaki boşluklara yerleştirildi ve sertleşmeleri için önerilen sürelerde bekletildi. Restoratif materyaller 4 grupta (kompomer, rezin modifiye cam iyonomer siman, yüksek viskoziteli cam iyonomer siman, Cention N) değerlendirildi. Biyomateryallerin üzerine $(2 * 2 \mathrm{~mm}$ çapında) silindirik kalıplar yardımıyla restoratif materyaller uygulandı. Veriler, tek yönlü ANOVA ve Tukey testleri kullanılarak analiz edildi.

Bulgular: Medcem Saf Portland siman ile en yüksek makaslama bağ dayanımı gösteren restoratif materyal grubu yüksek viskoziteli cam iyonomer siman grubu olurken, bunu sirasıyla kompomer, Cention N ve rezin modifiye cam iyonomer siman grupları izledi. Medcem MTA ile kompomer grubu arasındaki makaslama bağ dayanımı en yüksek olup, bunu sırasıyla Cention N, rezin modifiye cam iyonomer siman ve yüksek viskoziteli cam iyonomer siman grupları izlemiştir. NeoMTA'da ise makaslama bağ dayanımı en yüksek Cention N grubu ile, en düşük yüksek viskoziteli cam iyonomer siman grubu ile belirlendi.

Sonuç: Bu çalışmada kullanılan biyomateryaller ile pediatrik restoratif materyaller arasındaki makaslama bağ dayanımı umut vericidir ve vital pulpa tedavilerinde alternatif olarak düşünülebilir.

Anahtar Kelimeler: Makaslama bağ dayanımı, Kalsiyum silikat siman, Vital pulpa tedavisi.

Kabul: 22.12.2021

Yayın: 29.12.2021

Atıf / Citation: Duman S, Çalışkan A, Çalışkan S. Comparison of medcem MTA, medcem pure portland cement and neoMTA to pediatric restorative materials to shear bond strength. NEU Dent J. 2021;3:115-21.

* Corresponding Author / Sorumlu Yazar /

1. İnönü Üniversitesi Diș Hekimliği Fakültesi Pedodonti AD, Malatya, Türkiye

2. Protetik Diș Tedavisi, Özel Klinik, Eskișehir, Türkiye

3. Eskişehir Osmangazi Üniversitesi Diş Hekimliği Fakültesi Pedodonti AD, Eskişehir, Türkiye 


\section{INTRODUCTION}

The pulp, which is responsible for the formation and nutrition of dentin, also plays an essential role in the innervation and defense of the teeth. Vital pulp therapy is the process of placing a protective material on the pulp tissue damaged by deep caries or trauma after removing irritants. The protective material should be able to sustain the vitality of the pulp, block the bacterial invasion, resist to the chewing forces and support the formation of dentin bridge. ${ }^{1-4}$

Calcium hydroxide is widely used in vital pulp treatments. However, it causes failure in vital pulp treatments due to dystrophic calcification, weakness of dentin connection, low microleakage resistance, and tunnel defects. ${ }^{4-6}$ For these reasons, calcium silicate-based bioceramic materials have become more popular in vital pulp treatments. ${ }^{7}$

Calcium silicate cements have gained importance in vital pulp treatments due to their richness in calcium compounds and calcium hydroxide release. Mineral Trioxide Aggregate (MTA) is the first calcium silicate cement used in dentistry. It is a biocompatible material with excellent sealing properties, stimulating the formation of hard tissue, high alkaline structure, antibacterial activity and low solubility. ${ }^{8-10}$ Having superior biological properties, MTA has disadvantages such as long hardening time, difficult to apply, high cost and causing coloring. ${ }^{6,8,11}$ In addition, the fact that the acidification process applied to increase the bonding strength of resin restorations reduces the bonding strength of MTA has led to the continuation of the search for alternative materials to MTA. ${ }^{12}$ In order to eliminate the disadvantages of MTA, different comparison studies have been made with new generation calcium silicate cements produced by making changes in their content, ${ }^{13-19}$ and the results are promising.

In order to ensure the long-period success of vital pulp treatment, bond strength between pulp capping material and the restorative material should also be high. ${ }^{20}$ The most commonly used method for evaluating the adhesive properties of materials is the evaluation of their shear bond strength (SBS). ${ }^{21}$ In vitro tests on the SBS of different restorative and pulp capping materials provide researchers with objective information. ${ }^{22}$

The aim of this study was compare the SBS of Medcem Pure Portland Cement, Medcem MTA and NeoMTA used in vital pulp treatments to different pediatric restorative materials.

\section{MATERIALS AND METHOD}

\section{Preparation of Samples}

This research was carried out in Eskişehir Osmangazi University Research Laboratory. For the SBS test, $13^{* 7}$ acrylic blocks with 4 millimeters $(\mathrm{mm})$ diameter and $2 \mathrm{~mm}$ deep standard cylindrical cavities were prepared with diamond burs. Biomaterials prepared in accordance with the manufacturer's instructions, with $13^{*} 7$ pieces of each biomaterial, were placed in the spaces in the acrylic blocks. Excess biomaterials were removed from the surface with composite polishing disc to be levelled with the acrylic block. According to the manufacturer's recommendation, moist cotton pellets were placed on the samples and covered with temporary filling material (Cavit, $3 \mathrm{M}$ ESPE, America Inc., Norristown, PA, USA). Then the samples were kept at $37^{\circ} \mathrm{C}$ for 4 hours in distilled water.

Three pulp-capping biomaterials; NeoMTA (NuSmile Ltd. Houston, TX,USA), Medcem Pure Portland Cement (Medcem GmbH, Weinfelden, Switzerland), Medcem MTA (Medcem GmbH, Weinfelden, Switzerland) and four groups pediatric restorative materials was used (Table 1).

Group 1: Polyacid-modified composite resin (Compomer); In compomer groups (Dyract ${ }^{\circledR}$, Dentsply Sirona, USA), adhesive system (Single Bond, 3M ESPE, MN, USA) was applied to the surface of biomaterials for 10 seconds with a disposable bond brush. Then adhesive system was gently sprayed with air approximately 5 seconds and cured by light for 20 seconds. The compomer was deposited and cured by light for 40 seconds with LED device to polymerize the compomer.

Group 2: Resin modified glass ionomer cement (RMGIC); All materials in the RM-GIC groups (GC Fuji II LC Improved Capsules, GC Corporation, Tokyo, Japan) were supplied in an encapsulated form. Then, the capsules were activated and then mixed using a mechanical mixer according to their manufacturers' clinical instructions for use.

Group 3: High viscosity glass ionomer cement ( $\mathrm{HV}$ GIC); HV-GICs (EQUIA Forte ${ }^{\circledR}$ HT, GC Corporation, Tokyo, Japan) For each sample, an EQUIA Forte ${ }^{\circledR}$ HT capsule was mechanically mixed for 10 seconds according to the manufacturer's instructions, deposited in inside mold and closed on the surface by a teflon band. After waiting for 10 minutes at room temperature, the capping material (EQUIA Forte Coat, GC Corp.) was applied with the help of a microbrush and cured with light for 60 seconds. 
Table 1: Manufacturers and composition of the materials used

\begin{tabular}{|c|c|c|}
\hline Brand & Manufacturer & Chemical composition \\
\hline NeoMTA & $\begin{array}{l}\text { NuSmile Ltd. } \\
\text { Houston, TX,USA }\end{array}$ & $\begin{array}{l}\text { Powder: Tricalcium silicate, dicalcium silicate and tantalum } \\
\text { oxide Liquid: Water and proprietary polymers }\end{array}$ \\
\hline Medcem MTA & $\begin{array}{l}\text { Medcem GmbH, } \\
\text { Weinfelden, } \\
\text { Switzerland }\end{array}$ & $\begin{array}{l}\text { Portland cement (tricalcium silicate, dicalcium silicate, calcium oxide) } \\
\text { and zirconium oxide as radiopacifier }\end{array}$ \\
\hline $\begin{array}{l}\text { Medcem Pure } \\
\text { Portland Cement }\end{array}$ & $\begin{array}{l}\text { Medcem GmbH, } \\
\text { Weinfelden, } \\
\text { Switzerland }\end{array}$ & $\begin{array}{c}\text { Portland cement (tricalcium silicate, dicalcium silicate, } \\
\text { calcium oxide }\end{array}$ \\
\hline $\begin{array}{l}\text { Single Bond } \\
\text { Universal }\end{array}$ & $\begin{array}{l}\text { 3M ESPE, St. Paul, } \\
\text { MN, USA }\end{array}$ & $\begin{array}{l}\text { 10-methacryloyloxydecyl dihydrogen phosphate (MDP) monomer, } \\
\text { 2-hydroxyethyl methacrylate (HEMA), dimethacrylate resins, Vitrebond } \\
\text { copolymer, filler, ethanol, water } \\
\text { and silane }\end{array}$ \\
\hline $\begin{array}{l}\text { Polyacid-modified } \\
\text { composite resin } \\
\text { (Compomer) }\end{array}$ & $\begin{array}{l}\text { Dyract, Dentsply, } \\
\text { USA }\end{array}$ & $\begin{array}{l}\text { UDMA, carboxylic acid modified dimethacrylate, TEDGMA, } \\
\text { trimethylcrylate resin BHT, UV stabiliser, strontium-alumino-sodium- } \\
\text { fluorophospor-silicate glass, iron oxide }\end{array}$ \\
\hline $\begin{array}{l}\text { New resinous } \\
\text { fluoride-releasing } \\
\text { materials (Cention } \\
\quad \mathrm{N})\end{array}$ & $\begin{array}{l}\text { Ivoclar Vivadent } \\
\text { AG, Schaan, } \\
\text { Liechtenstein }\end{array}$ & $\begin{array}{l}\text { Powder: Calcium fluorosilicate glass, Barium-aluminum silicate glass, } \\
\text { Calcium-barium-aluminum fluorosilicate glass, Ytterbium trifluoride, } \\
\text { Isophiles, Initiator, color pigment Liquid: UDMA,DCP, Aromatic and } \\
\text { aliphatic UDMA,PEG-400 DMA,initiator, stabilizer }\end{array}$ \\
\hline $\begin{array}{l}\text { Resin modified } \\
\text { glass ionomer; } \\
\text { (GC Fuji II LC } \\
\text { Improved) }\end{array}$ & $\begin{array}{l}\text { GC Corporation, } \\
\text { Tokyo, Japan }\end{array}$ & $\begin{array}{l}\text { Fluoroaluminosilicate glass, polyacrylic caid, HEMA,resin,tartric asit, } \\
\text { distilled water. }\end{array}$ \\
\hline $\begin{array}{l}\text { High viscosity glass } \\
\text { ionomer cements } \\
\text { (EQUIA Forte } 囚 \mathrm{HT})\end{array}$ & $\begin{array}{l}\text { GC Corporation, } \\
\text { Tokyo, Japan }\end{array}$ & $\begin{array}{l}\text { Powder: Fluoroaluminosilicate glass, polyacrylic acid, iron oxide Liquid: } \\
\text { polybasic carboxylic acid, water }\end{array}$ \\
\hline
\end{tabular}

Grup 4: New resinous fluoride-releasing materials; Cention N (CN, Ivoclar Vivadent AG, Schaan, Liechtenstein) were filled into molds by mixing powder and liquid according to the manufacturers' instructions.

A cylindrical mold that (deep:2mm, height: $2 \mathrm{~mm}$ ) made of polyethylene was used to place the restorative materials to be applied on the biomaterials (Figure 1).

\section{Shear bond strength test}

All samples were fixed to a universal testing machine (MOD Dental MIC-101, Esetro Smart Robotechnologies, Ankara, Turkey) (Figure 2). Failure force of each sample was measured in Newtons by applying a force parallel to the long axis of the bonding area until failure occurred at a speed of $1 \mathrm{~mm} /$ minute. Then, the failure value for each sample was recorded in MPa by a single observer. 
Figure 1: Preparation of the samples set up used in the study

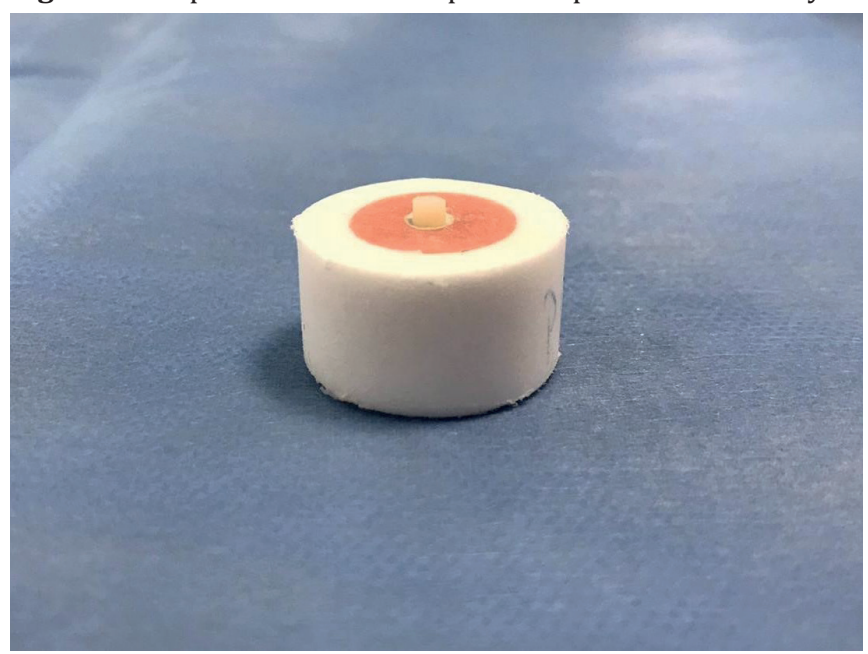

Figure 2: Universal testing machine

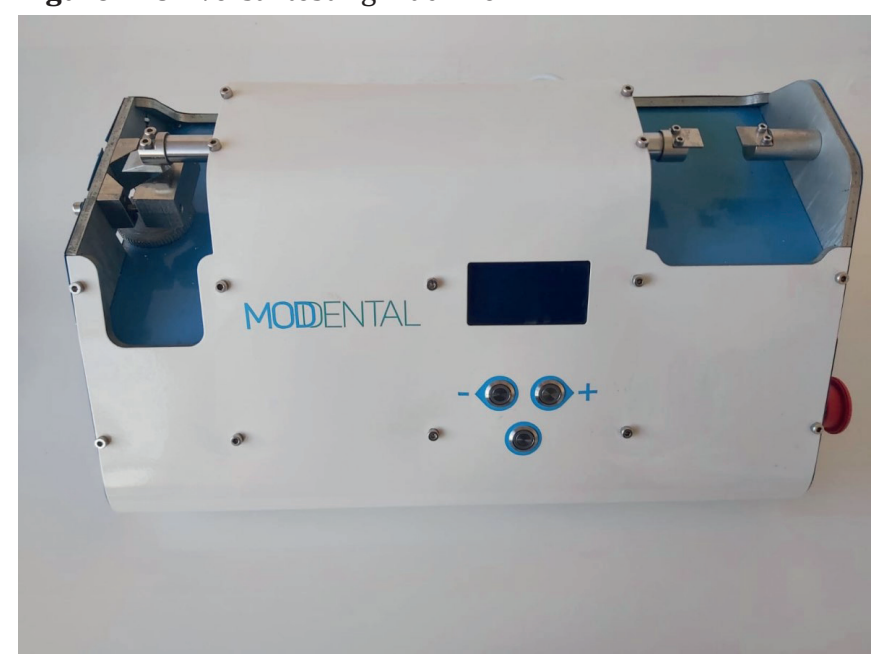

\section{Statistical analysis}

Data were analyzed using Microsoft Excel 2010 (Microsoft Corporation, USA) and SPSS 21.0 (IBM, Chicago, USA) programs. One-way-ANOVA was used for the statistical evaluation of obtained data. If there was a difference, the Tukey test was used to determine which groups differ. P-values of $<0.05$ were regarded as statistically significant.

\section{RESULTS}

The group showing the highest SBS with Medcem Pure Portland cement was HV-GIC, followed by the compomer, $\mathrm{CN}$ and RM-GIC groups, respectively. The
SBS between Medcem MTA and compomer group was the highest, followed by CN, RM-GIC and HVGIC groups, respectively. On the other hand, NeoM$\mathrm{TA}$, was determined by the highest SBS with the CN group and the lowest with the HV-GIC group (Table 2).

In the compomer and $\mathrm{CN}$ groups, the biomaterial with the highest SBS was Medcem MTA. The biomaterial with the highest SBS in the RM-GIC and HV-GIC groups was Medcem Pure Portland Cement. The biomaterial with the lowest SBS was found to be $\mathrm{Ne}$ oMTA in all of the restorative material groups, except for RM-GIC group. RM-GIC group, the lowest SBS was determined by Medcem MTA (Table 2).

Table 2: Mean (standard deviations) for shear bond strength (SBS) in the groups tested

\begin{tabular}{|c|c|c|c|c|}
\hline & $\begin{array}{l}\text { Medcem Pure } \\
\text { Portland }\end{array}$ & Medcem MTA & NeoMTA & $\mathbf{p}$ \\
\hline HV-GIC (EQUIA Forte ${ }^{\circledR}$ HT) & $37.27 \pm 18.81$ & $5.76 \pm 3.63^{c}$ & $3.60 \pm 2.46^{b}$ & 0.333 \\
\hline Cention N (CN) & $27.73 \pm 17.46$ & $38.2 \pm 17.06^{b}$ & $23.13 \pm 9.38^{\mathrm{a}}$ & 0.498 \\
\hline RM-GIC (GC Fuji II LC Improved) & $9.80 \pm 5.33$ & $6.06 \pm 5.75^{c}$ & $8.83 \pm 10.18^{\mathrm{a}, \mathrm{b}}$ & 0.821 \\
\hline Compomer (Dyract $囚$ ) & $33.53 \pm 6,05^{2}$ & $66.66 \pm 6.67^{\mathrm{a}, 1}$ & $7.93 \pm 1.42^{\mathrm{a}, \mathrm{b}, 3}$ & $0.000^{*}$ \\
\hline $\mathbf{p}$ & 0.607 & $0.000^{*}$ & $0,043^{*}$ & \\
\hline
\end{tabular}

One-way-ANOVA -Tukey Test, row: number, column: letter

HV-GIC: High viscosity glass ionomer cement, RM-GIC: Resin modified glass ionomer cement

*There was a statistically significant difference 


\section{DISCUSSION}

Calcium silicate cements are used in, pediatric dentistry, endodontics and dental traumatolog. Many calcium silicate-based cements used for therapeutic applications have slight variations in composition and manufacturing process. ${ }^{13}$ MTA, which is widely used in tricalcium-silicate cements, has given positive results in clinical studies, but has led to new searches due to its disadvantages such as its price and long setting time. ${ }^{6,8-11}$

Recently developed Medcem MTA unlike MTA; zirconium oxide was added instead of bismuth oxide as a radiopassivator. Medcem Pure Portland Cement is consists of mainly dicalcium and tricalcium silicate and hardens in the presence of moisture ${ }^{13-15} \mathrm{NeoM}$ $\mathrm{TA}$, which is currently used in vital pulp treatments, is a tricalcium silicate-based material containing tantalum as an opacifier and containing high amounts of sulfur. ${ }^{17,18}$ In spite of calcium silicate is the basic component, the attitude (bond strength, compressive strength, adhesion, fracture resistance) of these cements may differ depending on different radioactive softeners ${ }^{19}$ differences in production process, purity of ingredients and hydration products. ${ }^{16}$

SBS is clinically important for restorative material because the main displacement forces at the tooth restoration interface have a shearing effect. Great SBS values show high bonding between the cement and restorative material, which leads to less microleakage. It is thought that a bond strength ranging from 17-20 MPa may be needed to create gap-free restoration margins and to adequately stand contraction forces. ${ }^{23,24}$ According to the results of this study; Medcem Pure Portland Cement + RM-GIC group, Medcem MTA+ RM-GIC group and Medcem MTA+ HV-GIC groups displayed lower than values than 17 MPa. In the NeoMTA group, only the NeoMTA+CN group had a value higher than $17 \mathrm{MPa}$.

The clinical success of compomer, which is commonly used as a restorative material in pediatric dentistry, ${ }^{25}$ can be increased by the absence of gaps in margins and the good adhesion with pulp capping. It was observed that the studies were generally related to the SBS of calcium silicate-containing materials, glass ionomer and RM-GICs to the composite resin, ${ }^{25-27,29-34}$ and there were fewer studies on the bond strength of the compomer. ${ }^{21,35,36}$ In this regard, Tulumbacl et al.'s ${ }^{35}$ study found that the SBS of MTA and Biodentine was higher in compomer compared to RM-GIC. In this study, although the highest SBS with RM-GIC group was found with Medcem Pure Port- land Cement, this bond was lower than Compomer+ Medcem Pure Portland Cement, a resin-containing material. On the other hand, Medcem MTA was the biomaterial with the highest SBS in compomer. However, since there is no other study evaluating the SBS of Medcem MTA, Medcem Pure Portland Cement and NeoMTA using RM-GIC and compomer, the values in this study could not be compared. In this respect, this study is the first of its kind.

Glass-ionomer cements can be seen as basic filling materials as they are well-established, easy to use and economical. They are self-curing, do not require complex dental equipment, and are usually applied in bulk without adhesives. CN, which has been developed recently, can be used as an alternative restorative material in pediatric dentistry with its fluorine and calcium release and ease of application. Also CN; it has been suggested to have strength comparable to amalgam and aesthetics comparable to glass ionomers. ${ }^{37-39}$ In this study, CN showed the highest SBS with Medcem MTA, while HV-GICs was bonded with Medcem Pure Portland Cement.

In this study, a single bond system was used as an adhesive system, which does not require rinsing, which reduces technical sensitivity and shortens the application time. There are studies supporting this conclusion with superior bond strength after acid etching of MTA..$^{40,41}$ On the contrary, there are studies favoring self-etch systems ${ }^{42,43}$ or stating that adhesive mode is irrelevant. ${ }^{44}$ Conflicting findings between studies may be due to differences in MTA compositions and the adhesive systems used. Also in this study, restorative materials used in pediatric dentistry were chosen as restorative materials, and SBS was not compared with universal composites. However, the application of acid to the surfaces of biomaterials and the use of different adhesive systems may affect the bond strength to restorative materials. For this reason, further studies are needed to evaluate the SBS of Medcem MTA, Medcem Pure Portland Cement and NeoMTA with different restorative materials and adhesive systems.

\section{CONCLUSION}

Compomer and CN showed the highest SBS values with Medcem MTA, HV-GICs and RM-GIC showed the highest SBS with Medcem Pure Portland Cement. However, further in vivo studies are needed to examine the bond strength of different restorative materials with different calcium silicate-based cements. 


\section{REFERENCES}

1. Hargreaves KM, Cohen S, Berman LH. Cohen's pathways of the pulp: Mosby Elsevier; 2011.

2. Modena KCdS, Casas-Apayco LC, Atta MT, Costa CAdS, Hebling J, Sipert CR, et al. Cytotoxicity and biocompatibility of direct and indirect pulp capping materials. J Appl Oral. Sci. 2009;17:544-4.

3. Lee H, Shin Y, Kim S-O, Lee H-S, Choi H-J, Song JS. Comparative study of pulpal responses to pulpotomy with ProRoot MTA, RetroMTA, and TheraCal in dogs' teeth. J Endod. 2015;41:1317-24.

4. Bicer H, Bayrak S. Vital pulpa tedavisinde kullanılan kalsiyum silikat içerikli biyomateryallerin restoratif materyallere bağlanma dayanımının değerlendirilmesi. Selcuk Dent J. 2019;6:271-9.

5. Zhu L, Yang J, Zhang J, Peng B. A comparative study of BioAggregate and ProRoot MTA on adhesion, migration, and attachment of human dental pulp cells. J Endod. 2014;40:1118-23.

6. Asgary S, Eghbal MJ, Parirokh M, Ghanavati F, Rahimi H. A comparative study of histologic response to different pulp capping materials and a novel endodontic cement. Oral Surg Oral Med Oral Pathol Oral Radiol Endod. 2008;106:609-14.

7. Raghavendra SS, Jadhav GV, Gathani KM, Kotadia P. Bioceramics in endodontics-a review. J Istanb Univ Fac Dent. 2017;51:128-37.

8. Torabinejad M, Watson T, Ford TP. Sealing ability of a mineral trioxide aggregate when used as a root end filling material. J Endod. 1993;19:591-5.

9. Okiji T, Yoshiba K. Reparative dentinogenesis induced by mineral trioxide aggregate: A review from the biological and physicochemical points of view. Int J Dent. 2009;464280:12.

10. Guerreiro-Tanomaru JM, Chula DG, de Pontes Lima RK, Berbert FL, Tanomaru-Filho M. Release and diffusion of hydroxyl ion from calcium hydroxide-based medicaments. Dent Traumatol. 2012;28:320-23.

11. Makkar S, Vashisht R, Kalsi A, Gupta P. The effect of altered ph on push-out bond strength of biodentin, glass ionomer cement, mineral trioxide aggregate and theracal. Stomatol Glas Srb. 2015;62:7-13.

12. Kayahan MB, Nekoofar MH, McCann A, Sunay $H$, Kaptan RF, Meraji N, et al. Effect of acid etching procedures on the compressive strength of 4 calcium silicate-based endodontic cements. J Endod. 2013;39:1646-8.

13. Rajasekharan S, Vercruysse C, Martens L, Verbeeck R. Effect of exposed surface area, volume and environmental $\mathrm{pH}$ on the calcium ion release of three commercially available tricalcium silicate based dental cements. Materials. 2018;11:123.

14. Niu LN, Jiao K, Wang TD, Zhang W, Camilleri J, Bergeron $\mathrm{BE}$, et al. A review of the bioactivity of hydraulic calcium silicatecements. J Dent. 2014;42:517-33.

15. Prati C, Gandolfi MG. Calcium silicate bioactive cements:biological perspectives and clinical applications. Dent Mater. 2015;31:351-70.

16. Kouzmanova YI, Dimitrova IV, Gentscheva GD, Aleksandrov LI, Markova-Velichkova MG, Kovacheva DG. Comparative study of the phase formation and interaction with water of calcium-silicate cements with dental applications. Bulg Chem Com- mun. 2015;47:239-44.

17. Dammaschke T, Gerth HU, Zuchner H, Schafer E. Chemical and physical surface and bulk material characterization of white pro root MTA and two portland cements. Dent Mater. 2005;21:731-38.

18. Li Q, Coleman NJ. The hydration chemistry of Proroot MTA. Dent Mater J. 2015;34:458-65.

19. Duarte MAH, Minotti PG, Rodrigues CT, Zapata RO, Bramante CM, Tanomaru Filho M, et al. Effect of different radiopacifying agents on the physicochemical properties of white portland cement and white mineral trioxide aggregate. J Endod. 2012;38:394-7.

20. Tziafas D, Smith AJ, Lesot H. Designing new treatment strategies in vital pulp therapy. J Dent. 2000;28:7792.

21. Tunc ES, Sonmez IS, Bayrak S, Egilmez T. The evaluation of bond strength of a composite and a compomer to white mineral trioxide aggregate with two different bonding systems. J Endod. 2008;34:603-5.

22. Orhan DAI, Öz FT. Sık kullanılan bağlanma dayanım test metotları: Derleme çalışması. Turkiye Klinikleri J Dental Sci-Special Topics. 2011;2:31-40.

23. Davidson CL, de Gee AJ, Feilzer A. The competition between the composite-dentin bond strength and the polymerization contraction stress. J Dent Res. 1984;63:1396-9.

24. Al-Sarheed MA. Evaluation of shear bond strength and SEM observation of all-in-one self-etching primer used for bonding of fissure sealants. J Contemp Dent Pract. 2006;7:9-16.

25. Oskoee SS, Bahari M, Kimyai S, Motahhari P, Eghbal MJ, Asgary S. Shear bond strength of calcium enriched mixture cement and mineral trioxide aggregate to composite resin with two different adhesive systems. J Dent (Tehran). 2014;11:665-71.

26. Ajami AA, Jafari Navimipour E, Oskoee S, Kahnamoui M, Lotfi M, Daneshpooy M. Comparison of shear bond strength of resin-modified glass ionomer and composite resin to three pulp capping agents. J Dent Res Dent Clin Dent Prospect. 2013;7:164-8.

27. Oskoee SS, Kimyai S, Bahari M, Motahari P, Eghbal MJ, Asgary S. Comparison of shear bond strength of calcium-enriched mixture cement and mineral trioxide aggregate to composite resin. J Contemp Dent Pract. 2011;12:457-62.

28. Blumer S, Peretz B, Ratson T. The Use of restorative materials in primary molars among pediatric dentists in Israel. J Clin Pediatr Dent. 2017;41:199-203.

29. Manuja N, Pandit IK, Srivastava N, Gugnani N, Nagpal R. Comparative evaluation of shear bond strength of various esthetic restorative materials to dentin: An in vitro study. J Indian Soc Pedod Prev Dent. 2011;29:713.

30. Schmidt A, Schäfer E, Dammaschke T. Shear bond strength of lining materials to calcium-silicate cements at different time intervals. J Adhes Dent. 2017;19:129-35.

31. Shin JH, Jang JH, Park SH, Kim E. Effect of mineral trioxide aggregate surface treatments on morphology and bond strength to composite resin. J Endod. 2014;40:1210-6.

32. Alzraikat H, Taha NA, Qasrawi D, Burrow MF. Shear bond strength of a novel light cured calcium silicate 
based-cement to resin composite using different adhesive systems. Dent Mater J. 2016;35:881-7.

33. Cantekin K, Avci S. Evaluation of shear bond strength of two resin-based composites and glass ionomer cement to pure tricalcium silicate-based cement (Biodentine®). J Appl Oral Sci. 2014;22:302-6.

34. Ajami AA, Bahari M, Hassanpour-Kashani A, AbedKahnamoui M, Savadi-Oskoee A, Azadi-Oskoee F. Shear bond strengths of composite resin and giomer to mineral trioxide aggregate at different time intervals. J Clin Exp Dent. 2017;9:e906-11.

35. Tulumbaci F, Almaz ME, Arikan V, Mutluay MS. Shear bond strength of different restorative materials to Mineral Trioxide Aggregate and Biodentine. J Conserv Dent. 2017;20:292-6.

36. Buldur B, Öznurhan F, Kayabași M, Sahin F. Shear bond strength of two calcium silicate-based cements to compomer. Cumhuriyet Dent J. 2018;21:18-23.

37. Verma V, Mathur S, Sachdev V, Singh D. Evaluation of compressive strength, shear bond strength, and microhardness values of glass-ionomer cement Type IX and Cention N. J Conserv Dent.2020;23:550.
38. Scientific Documentation: Cention N Ivoclar Vivadent AG Research \& Development Scientific Service. 2016.

39. Özmen B. Yeni bir restoratif materyal" Cention N". NEU Dent J. 2021;3:84-90.

40. Cengiz E, Ulusoy N. Microshear bond strength of tricalcium silicate-based cements to different restorative materials. J Adhes Dent. 2016;18:231-7.

41. Meraji N, Camilleri J. Bonding over dentin replacement materials. J Endod. 2017;43:134-9.

42. Krawczyk-Stuss M, Nowak J, Bołtacz-Rzepkowska E. Bond strength of Biodentine to a resin-based composite at various acid etching times and with different adhesive strategies. Dent Med Probl. 2019;56:39-44.

43. Colak H, Tokay U, Uzgur R, Uzgur Z, Ercan E, Hamidi MM. The effect of different adhesives and setting times on bond strength between Biodentine and composite. J Appl Biomater Funct Mater. 2016;14:e217-22.

44. Kalyoncuoglu E, Keskin C, Acar DH, Gonulol N. The bond strength of universal adhesives with different acidities to calcium silicate-based materials. Clin Exp Health Sci. 2021;11:170-74. 